$\frac{10.5 .5 .5}{\text { V.s.J. }}$

\title{
複合型曝気循環装置の強制水循環に関する実地調査実験* 一浅層の水温躍層破壊過程と循環構造の可視化一
}

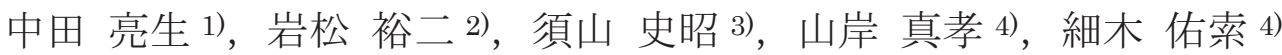

\section{Field Experiment on Forced Water Circulation}

\author{
by Multifunctional Aerator in a Dam Reservoir
}

- Visualization of Thermocline Destruction Process and Flow

\author{
Structure in Shallow Layer -
}

\begin{abstract}
Akinori NAKATA, Yuji IWAMATSU, Fumiaki SUYAMA, Masataka YAMAGISHI and Yusaku HosOKI

ABSTRACT

Multifunctional aerators were installed in Hiyoshi Dam in Kyoto to oxygenate the deep anaerobic water layer and destroy the thermal stratification in the shallow layer. In August of 2011, field experiments were performed to ascertain the effect of thermocline destruction. In the experiments, the temperature and flow distributions were directly measured near one of the aerators with a high spatial and temporal resolution, and a video camera clearly captured images of water containing sediment that was lifted from the deep layer. Analysis of the data confirmed that the thermocline in the shallow layer was destroyed within an $8-10 \mathrm{~m}$ radius of the aerator and to a $3 \mathrm{~m}$ depth in a period of $10 \mathrm{minutes}$, and a horizontal intrusion was present at a depth of $2.7 \mathrm{~m}$ in the external region. In addition, to assess the performance of the aerator for thermocline destruction, the thermal energy, potential energy and circulation flow rate were also investigated.
\end{abstract}

Keywords: Forced water circulation, Air bubble plume, Field experiment, Thermocline, Stratified reservoir

\section{1. はじめに}

ダム貯水池のような閉鎖性水域における水質問題には, アオコや淡水赤潮と呼ばれる藻類の異常増殖, 深層の水域 の嫌気化（酸素の欠乏）とそれに伴う底泥の重金属類等の 溶出, 洪水後の濁水が長期間にわたって停滞する濁水問題, 夏季に深層の低温水が放流されてしまう冷水害などがあ る。中でも特に深刻な問題は，藻類の異常増殖と深層水の 嫌気化であろう。これらの問題は, 水域内の循環状況, 流 入する栄養塩類濃度, 日射, 気温などの複合的な要因で発 生する，通常，夏季においては，強い日射と気温の上昇が 表層の水温を上昇させ, その鉛直勾配が大きい安定した密

* 原稿受付 2014 年 9 月 8 日

1）正会員 大阪電気通信大学 工学部（干572-8530 大阪府寝屋川 市初町 18-8, E- mail : a-nakata@isc.osakac.ac.jp)

2) 水資源機構 琵琶湖開発総合管理所

3) 大阪電気通信大学大学院 工学研究科

4）丸島アクアシステム 環境エンジニアリング部
度成層, いわゆる水温躍層を形成し, 結果として, 水域の 鉛直混合が抑制されて問題が顕著化する.

以上のような水質問題を改善する主な対策として, 種々 の曝気循環装置が導入される。一般に，地上よりコンプレ ッサーを用いて, 空気を十数から二十メートル程度の水深 で開放し，酸素を供給して嫌気化を直接的に改善する。さ らに，その空気塊または気泡群が，周囲の水を連行するこ とによって強制的な水循環を作り出し, 成層の破壊と発達 抑制, さらには藻類の有光層への滞留などを防止する。

曝気循環装置は一般に, 水質改善要求やその規模に応じ て, 次の 4 方式 ${ }^{1)}$ に分類される。

（1）全層循環 : 底層から散気し，全層にわたって循環さ せて可能な限り躍層を破壊する。

（2）躍層低下: 躍層よりやや下方から散気し，躍層をよ り深層に下げる.

（3）浅層（表層）循環 : 躍層またはそれより上方で散気 し, 躍層を維持した状態で浅層域での水循環を実現する. 
（4）深層（水）曝気：嫌気化した深層水を取り込んで酸 素を供給し, 再度深層に返す（躍層を維持して嫌気化を抑 制する)。

京都府南丹市の日吉ダム貯水池に, 2009 年に導入され た曝気循環装置は，上記の（2）躍層低下または（3）浅 層循環方式（躍層の位置によって方式が変わる）に加え,

(4) 深層曝気方式を, 選択的に実現できる複合方式の新 型装置である，その装置の性能評価の一環として，著者ら はこれらの効果を現地で調査する機会を得た。ここでは, 本装置の浅層循環機能の詳細な評価を目的とし, 気泡噴流 が水温躍層を破壞する過程と, それを引き起こす水循環構 造について調査した結果について報告する。

曝気循環装置による水循環に関しては, それが流体力学 的な観点からも興味深、現象である. 貯水池などの密度成 層を対象とした模型実験または理論的な研究は数多く,

Mcdougall $^{2)}$ の実験的研究が先駆的で, Asaeda $ら^{3)}$ の成果は 現在も, 曝気による水域内の基本的な循環構造の把握や循 環（揚水）流量設計に多く活用されている. 現地において その流動現象を把握するための調査も多数報告されてお り, 例えば国内のダムでは, 松梨ら ${ }^{4)}$ が, 全層曝気循環装 置の 1 つである空気揚水筒を対象とし, 気泡弾の放出水面 近傍で電磁流速計を用いて計測を行い, 流速分布から連行 流量と効率を求めている。 その他にも丹羽ら ${ }^{5)}$, 豊島 ${ }^{6)}$, 梅田ら ${ }^{7)}$, 岩松ら ${ }^{8)}$ など, 海外では, Imberger $ら^{9)}$, McGinnis

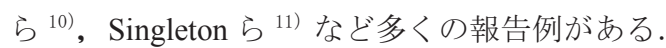

以上の研究から得られた知見の一つは, 気泡噴流によっ て連行された低温の水塊が, 浅層における高温のそれと混 合し, その後, 密度流として水平方向に広がるイントリュ ージョンを含む循環構造が, 広範囲の貯水池の水質を管理 する上で重要であるという点である.しかしながら,この ような気泡噴流が引き起こす水循環について, その 2 次元 鉛直断面の構造を時系列で詳細に現地観測した例は, Imberger $5^{9)}$, 梅田 ${ }^{7)}$, 岩松ら ${ }^{8)}$ に限られる。

Imberger $ら^{9)}$ は, Wungong Dam 貯水池（オーストラリ ア）に設置された散気装置から放出される気泡噴流の近傍 で，水温や塩分濃度などを観測し，密度成層とイントリュ ージョンの構造を示した他，2個の音響センサーから複合 された音響画像よりサーマル構造を可視化している.さら にそれらの結果から, 気泡噴流のエネルギー変換過程など を明らかにしている. 梅田ら ${ }^{7)}$ は, 湖底設置型散気装置が 複数台設置された土師ダム貯水池（広島県）を対象に， $\mathrm{ADCP}$ (超音波多層流向流速計）を取り付けた観測船の电 航による流動空間分布計測, 曝気の近傍に設置した ADCP による 1 ケ月間の流速分布計測および多水深に取り付け た水温計から水温成層の状態を計測し, イントリュージョ ンの特性を詳細に把握している. 一方, 岩松ら ${ }^{8)}$ は本研究 に先立って 2010 年夏, 日吉ダムに設置された新型曝気循 環装置が，運転開始より約 1 時間後の定常な貯水池状態に
おいて, 装置近傍の鉛直断面の水温・流速分布を観測し， 装置上方の直接的な躍層破壊範囲と, そこから水平に広が るイントリュージョンを可視化し, 散気部形状の違いによ る気泡噴流とその流動状態の相違について検討している.

本研究では, 岩松らが実施した上記の調査実験に引き続 き, 本装置の浅層循環機能の詳細な評価を目的とし, 深層 からの水連行による躍層破壊の進行過程と循環構造を, さ らに高い空間・時間分解能で調査する実験を, 2011 年 8 月に行った. 実験では第一に, 温度計を取り付けた計測ケ ーブルを, 装置より北側 $20 \mathrm{~m} \times$ 深さ $20 \mathrm{~m}$ の範囲で掃引し、 2 次元断面の水温分布を 1 分ごとの 30 分間にわたって計 測した。第二に，装置周辺の流れが安定した状態で，2 次 元の電磁流速計を装置近傍に設置して流速・流向を計測し た. 以上の計測を, 曝気循環装置への供給空気流量が異な る条件について行い, 空気流量による影響も調べた. また, 当時の貯水池では実験前から中・深層でかなり濃い濁水が 滞留しており, 幸いにも装置から解放される気泡噴流がそ れを連行し, 貯水池表面に広がる結果となった。 そこで実 験中, ビデオカメラを用いて貯水池表面を撮影し，その濁 水の広がりから, 水温と流速の計測結果に対応する流れの 可視化映像を得た. 以上の結果から, 躍層破壊の進行過程 と循環構造を，これまでにない空間・時間解像度で明らか にするとともに, 躍層破壊の効果と循環流量を定量的に評 価し, 装置の浅層循環性能を確認したので報告する。

\section{2. 日吉ダム貯水池と複合型曝気循環装置}

\section{1 日吉ダム貯水池（天若湖）}

実験の対象とする日吉ダム（京都府南丹市日吉町）は， 淀川の総合開発の一環として, 淀川水系桂川に建設された 多目的（洪水調節，不特定利水，上水道）ダムで，堤頂長 は $438 \mathrm{~m}$ ，堤高は $67.4 \mathrm{~m}$ である。 その貯水池の堤体近傍の 水域図をFig. 1 （全体図を左下に表示）に示す。貯水池は 天若湖 (あまわかこ) とも呼ばれ, 貯水池の面積は $2.74 \mathrm{~km}^{2}$, 最大貯水量は 6,600 万 $\mathrm{m}^{3}$ である. 図中の点線で描いた丸 （ 2 箇所）の位置の水中に, 新型の曝気循環装置が 2 基設 置されている。これら装置の上流側にみられる破線は, 流 木の侵入を防ぐ網場で, その中央には水温, 水質の鉛直分 布を 6 時間ごとに計測する自動観測装置が設置されてい

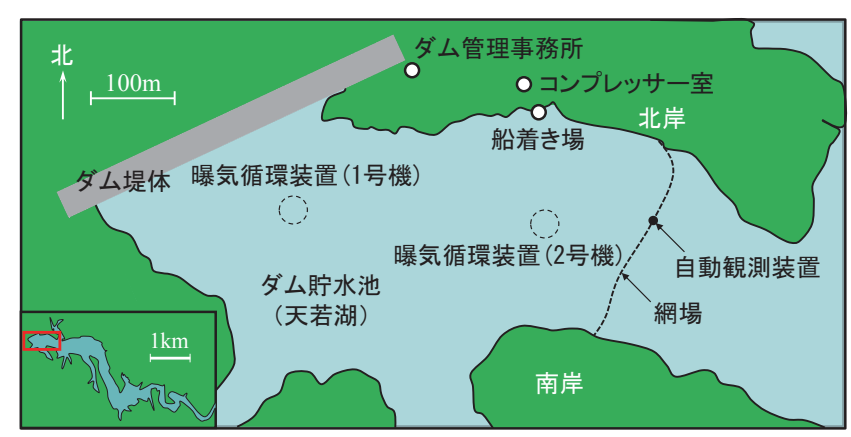

Fig. 1 Hiyoshi dam and its reservoir (Amawakako). 
る. ダム湖の北岸には, 曝気循環装置への空気供給のため のコンプレッサー室 $(15 \mathrm{~kW} \times 2$ 台 $)$, 船着き場がある.

\section{2 複合型曝気循環装置}

日吉ダム貯水池に 2009 年，複合型曝気循環装置として 導入された新型装置の概略をFig. 2 (中央) に示す. 当該 装置は, 地上より圧縮機によって貯水池深層に送り込まれ た空気塊を, 湖底に垂直に設置された装置本体 (二重構造 の管、最大直径 $2 \mathrm{~m}$ ，長さ $16 \mathrm{~m} ）$ の内側管内最下部から上 方に散気する。散気された空気は，内側管内を上昇する際 に，その下端の開口部より深層水を取り込んで連行しなが ら酸素を供給する.酸素が供給された深層水は内側管上端 の開口部まで上昇し, その後, 外側管に流れ込んで下降し, 再び深層に返される (深層曝気).この過程で, 全供給量 の $90 \%$ 程度と見積もられる未溶解空気は, 装置上方で気液 分離されて装置外部の水中に直接開放され, その浮上作用 が周囲の浅層水を連行して循環させる（浅層循環）。未溶 解空気開放部の真上には, 直径 $1 \mathrm{~m}$, 高さ $40 \mathrm{~cm}$ の盃形状 のコーンが設置され, 空気塊を分断して気泡群として放出 し, 効果的に水を連行するように工夫されている.ただし, 洪水後の濁水や冷水が浅層に巻き上げられて問題になる など，浅層循環を行うことが水質改善に寄与しない場合に は, 装置上方に接続された排気管を通じてこれを水面上に 解放し, 浅層に影響を与えることなく深層曝気のみを行う。

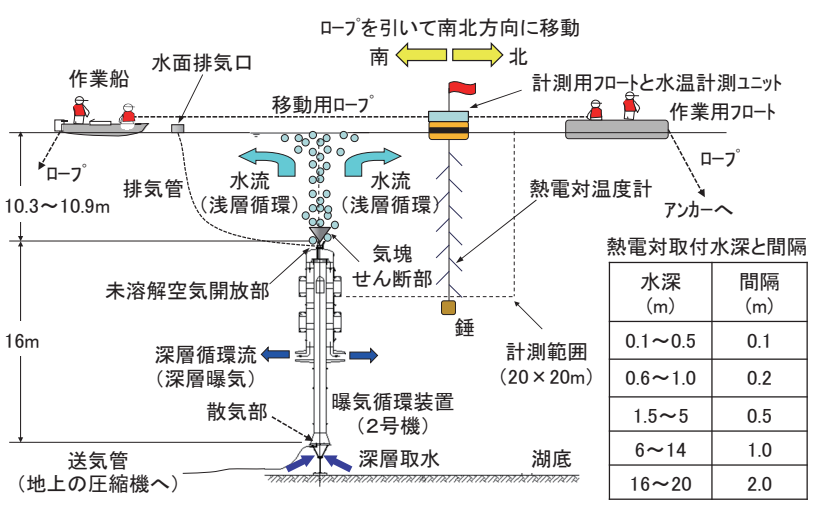

Fig. 2 Composed aerator and measurement method of water temperature in shallow layer.

\section{3. 調查実験実施期間中の貯水池環境}

調査実験は 2011 年の 8 月 9 日（予備実験）および 8 月 16〜18 日（本実験）に実施した。 4 日間の日中の天候は概 ね晴れで, 24 時間を通じて降水もほとんどなく, 強固な 躍層が形成される典型的な夏季の貯水池環境となった.今 回の実験対象としたのは 2 号機 (Fig. 1 の水域内東側)で, 実験期間中は, 貯水池の流入 - 放流量も少なく, その水位 は 8 月 9 日が 177.2EL.m, 8 月 16〜18日が 175.4〜174.8EL.m (平均 175.1EL.m) と安定していた。これより, 気塊（気 泡）が放出される装置上部の水深は，それぞれ $12.7 \mathrm{~m}$ と $10.9 \sim 10.3 \mathrm{~m}$ （平均 $10.6 \mathrm{~m}$ ） となる. また, 実験期間中, 水 深 $10 \mathrm{~m}$ 近傍より深い中・深層で, 濃い濁水の滞留が観測
されていた。 これは, 後述する水温および流速の計測結果 と対応する映像が得られる好条件となった。

\section{4. 水温計測による躍層破壊過程の可視化}

\section{1 計測の方法}

水温計測の基本的な方法を示した概略図を Fig. 2 に示 す. 28 個の熱電対（K 型，素線径 $0.3 \mathrm{~mm}$ ）を取り付けた 長さ $20 \mathrm{~m}$ の計測用ロープを, 計測用フロートと錘 (真鍮, 質量 $6.8 \mathrm{~kg}$ ）を用いて，水面から鉛直に吊るした。計測用 フロートの上には，ポータブルデータロガー（江藤電気， THERMIC 2300A） 6 台を格納した水温計測ユニットが搭 載されている。熱電対の取り付けは，Fig. 2 の右下に示す ように, 水温の鉛直変化の大きい水面付近を比較的密にし た．計測用フロートは，移動用ロープを使用して，曝気装 置真上から北へ向かって $20 \mathrm{~m}$ の距離の水面上を，40s かけ て等速で移動（速度 : 約 $0.5 \mathrm{~m} / \mathrm{s}$ ）させた。データロガーの 計測周期は $0.2 \mathrm{~s}$ に設定したので, 断面の水平方向の分解能 は $10 \mathrm{~cm}$ となる。計測用フロートの移動は，作業用フロー トと作業船上の作業員が, 移動用ロープの引つ張りと手繰

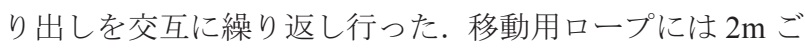
とに印をつけ, 装置真上を貯水池南岸から北岸に向かって 南北に張った位置決め用のロープに沿うようにした。事前 に移動作業のリハーサルを行い, フロートの 1 移動 (20m) にかかる時間（40s）の誤差は概ね $1 \mathrm{~s}$ 以内を実現した。

計測はまず, 水温の初期值を得るために装置稼働直前に 行った。その後速やかに装置を稼働し, 曝気直後（気泡の 水面放出直後）から再開し, 往路の計測 $(40 \mathrm{~s})$ の後, $20 \mathrm{~s}$ の待機時間を設け，復路の計測（40s）を行った。このよ うに, 計測と待機を 30 分間 (15 往復) 繰り返した. なお, 計測用ロープには相当の流水抵抗が作用し, それが鉛直よ り最大約 30 傾くため, 得られた水温データは後に, 移動 速度の誤差と併せて位置補正 (水平と深さ方向)を行った。

曝気循環装置への供給空気流量 $Q_{a}$ は, 大気压 $p_{0}$ で 1.4 と $0.7 \mathrm{Nm}^{3} / \mathrm{min} の 2$ 通りとし,計測（装置稼働）日時は，本 実験 1 日目（8月 16 日）の 12:26から $\left(Q_{a}=1.4 \mathrm{Nm}^{3} / \mathrm{min}\right)$ と, 同 2 日目 (8月 17 日) の 11:58 から $\left(Q_{a}=0.7 \mathrm{Nm}^{3} / \mathrm{min}\right)$ である. 少なくとも計測前 12 時間は装置を運転せず，貯 水池には可能な限り人為的な擾乱が無いように配慮した.

\section{2. 計測結果}

供給空気流量 $Q_{a}$ が 1.4 と $0.7 \mathrm{Nm}^{3} / \mathrm{min}$ の場合について得 られた鉛直水温分布の例を Fig. 3 から 6 に示す. 1 断面の 計測には 40 秒を要するが，時刻 $t$ はすべて計測開始時刻 を示す. Fig. 3 から 5 のコンター図はいずれも，横軸が装 置から北に向から半径座標 $r$, 縦軸が水深 $d$ を示す. また,

Fig. 3 右と 6 は, 曝気前後の代表的な水温分布を半径 $r$ が $0,5,10,15 \mathrm{~m}$ で抽出して示している. 装置の散気部は, 半径 $r=0 \mathrm{~m}$, 水深 $d=10.9 \sim 10.3 \mathrm{~m}$ の位置にある. ただし, その位 置での計測值は，噴流が計測点を東西方向に $1 \sim 2 \mathrm{~m}$ 移動 
させてしまうための誤差を含む.

曝気前は, 水平方向に概ね一様な成層が形成されている ことは，これまでの実験経験からも明らかである。しかし ながら, 計測の方法でも説明したように, 計測用ロープが 流水抵抗により傾くため, 得られた元データの水温分布も それに応じて変化する. そこで, 曝気前の水温分布が, 水 平方向に一様になるよう, ロープが直線と仮定してその傾 き角度を時系列で推定し, 水平と深さ方向の位置補正量を 求めた. この補正量を, 曝気後の水温分布の位置補正に一 律に適用している．そのため，水深が 15〜20m のデータ が一部欠損するので，その領域は省略してある。

曝気前の水温分布から, 浅層の水温躍層 (水温の急変層) は水深 $3 \mathrm{~m}$ 付近にあることがわかる. 空気流量 $Q_{a}$ が $1.4 \mathrm{Nm}^{3} / \mathrm{min}$ の場合の曝気後の温度コンター図の代表例を, Fig. 4 に時系列で示している。計測された全てのデータよ
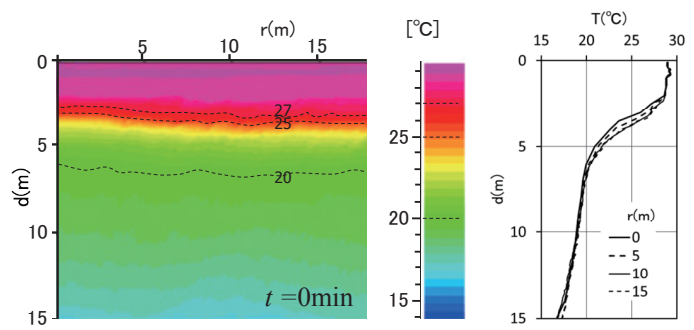

Fig. 3 Initial condition of water temperature near aerator (2011/8/16 12:26).
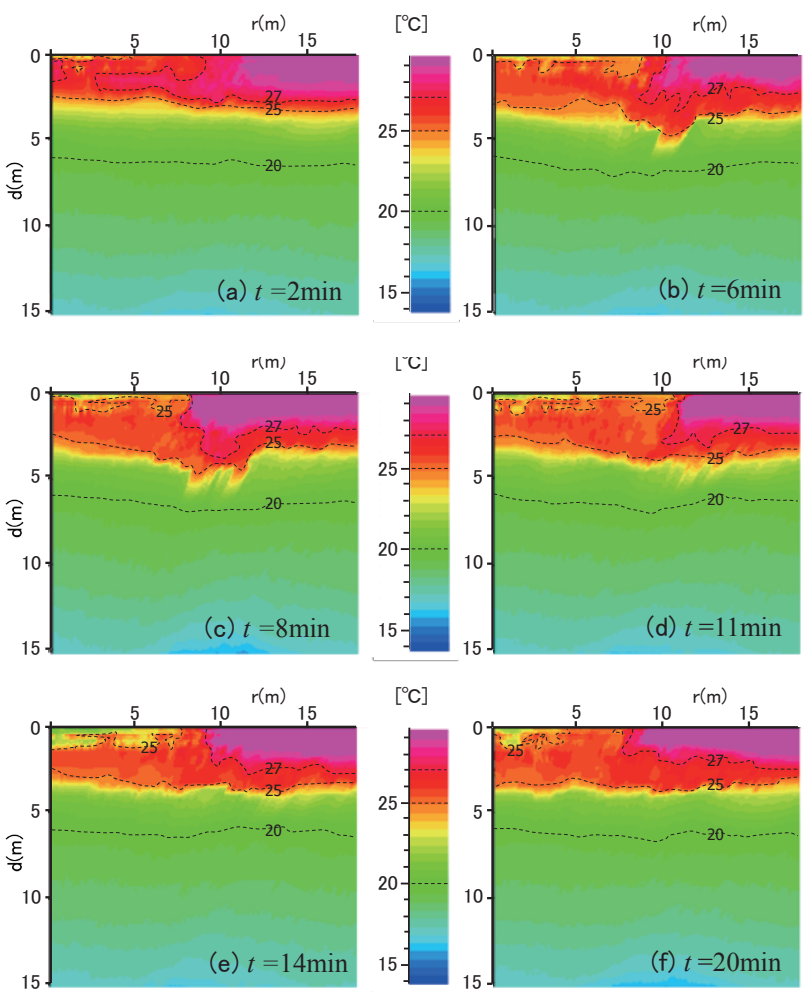

Fig. 4 Contour diagrams of water temperature near aerator for $Q_{a}=1.4 \mathrm{Nm}^{3} / \min (2011 / 8 / 1612: 26)$.
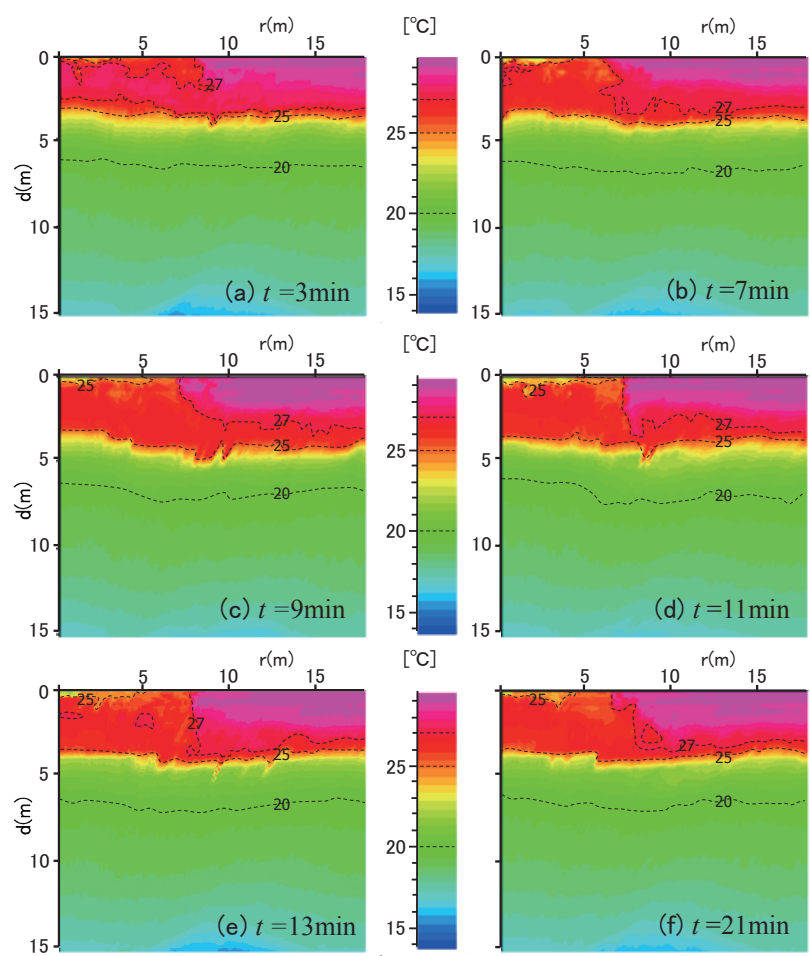

Fig. 5 Contour diagrams of water temperature near aerator for $Q_{a}=0.7 \mathrm{Nm}^{3} / \min \left(t_{0}=2011 / 8 / 1711: 58\right)$.
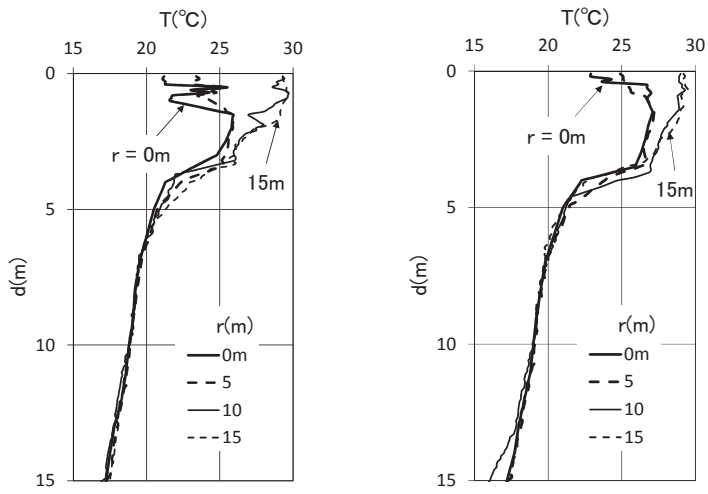

(a) $Q_{a}=1.4 \mathrm{Nm}^{3} / \mathrm{min}, t=14 \mathrm{~min} \quad$ (b) $Q_{a}=0.7 \mathrm{Nm}^{3} / \mathrm{min}, t=13 \mathrm{~min}$ Fig. 6 Vertical distribution of water temperature near aerator. り判断すると、気泡によって下層から連行されてきた冷水 が, その上方で徐々に拡がり, 曝気開始より概ね 10 分で, 半径 $r$ が約 $10 \mathrm{~m}$, 水深 $d$ が約 $3 \mathrm{~m}$ までの範囲で安定した冷 水塊を形成する。この冷水塊は時間が経過しても拡大せず, その境界は半径約 $2 \mathrm{~m}$ の振幅で時間的に変動している.

供給空気流量 $Q_{a}$ が $0.7 \mathrm{Nm}^{3} / \mathrm{min}$ の場合について得られた 結果はFig. 5 に同じ様式で示している.この場合について も, 先と同様な躍層の破壊過程がみられる. ただし, 冷水 塊の半径 $r$ は, 曝気流量が多い $1.4 \mathrm{Nm}^{3} / \mathrm{min}$ の場合に比べ てやや小さい約 $8 \mathrm{~m}$ となっている.

\section{3. 定点計測による結果}

冷水塊が拡がる半径 $r$ が $10 \mathrm{~m}$ の計測点において, Fig. 2 に示した水温計測装置を固定し, 温度分布の時系列変化を 
計測した。曝気時間は本実験 3 日目（8月 18 日）の 9:44 $\sim 10: 23\left(Q_{a}=1.4 \mathrm{Nm}^{3} / \mathrm{min}\right.$ の場合) と, 同 10:51 12:36 ( $Q_{a}$ $=0.7 \mathrm{Nm}^{3} / \mathrm{min}$ の場合) である. 結果の一部を Fig. 7 に示す. 図（a）に示寸空気流量が多い場合には, 躍層破壊の半径 が平均 $10 \mathrm{~m}$ であるため, 曝気中の温度変化が水面付近で 明瞭に確認できる. 曝気前には浅層で水温 $27^{\circ} \mathrm{C}$ 以上の領 域が広範囲に見られるが、曝気開始以降にほとんど消失し ている。ただし、この状態は，曝気を停止すると速やかに 元に戻る. 興味深い点は, 曝気中, 水深 $0 \sim 4 \mathrm{~m}$ で,時間軸 に直行する波状の温度変化が確認できることである.これ を詳細に示寸ため，水深 $\mathrm{d}$ が $1.5 \mathrm{~m}$ における水温の時系列 図を, コンター図の下に併記している。曝気開始数分で, それまで $29^{\circ} \mathrm{C}$ 程度だった水温が約 $3^{\circ} \mathrm{C}$ 低下しているが, そ の後明らかに大きく変動している。先に述べたように，こ れは破壊範囲が拡張・収縮を繰り返しているためと考えら れる. 周期は 1 2 分である. 一方, 図 (b) に示寸曝気流 量の少ない場合には，躍層破壊の半径が平均 $8 \mathrm{~m}$ であるた め，それが計測点まで十分に届いていない。したがって， 浅層において水温 $27^{\circ} \mathrm{C}$ 以上の領域が, 相対的に多く残存 している.ただし, 破壊範囲が拡張・収縮を繰り返すため, 曝気流量が多い場合より, 相対的に高い温度帯で変動して いる。

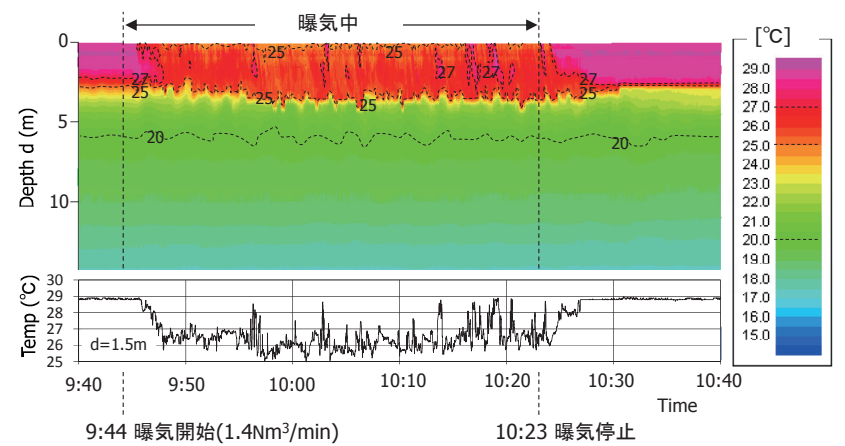

(a) $Q_{a}=1.4 \mathrm{Nm}^{3} / \mathrm{min}$

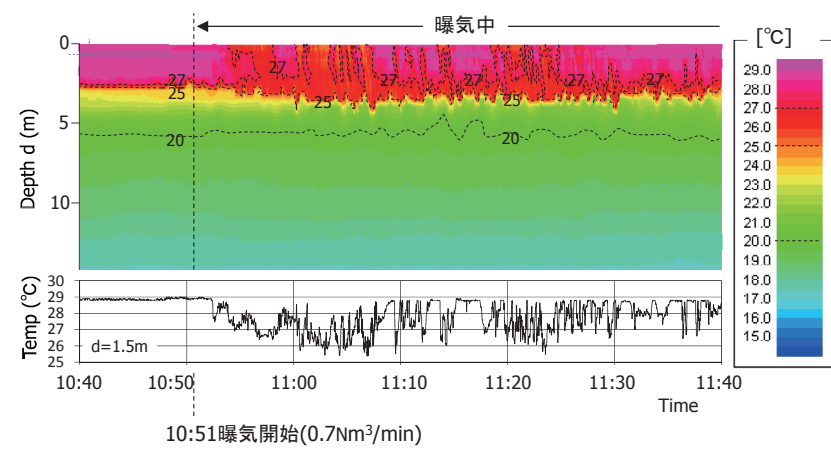

(b) $Q_{a}=0.7 \mathrm{Nm}^{3} / \mathrm{min}$

Fig. 7 Time history of water temperature at a fixed point of $r=10 \mathrm{~m}$.

\section{4. 躍層破壊の定量的評価とイントリュージョン}

装置真上における躍層の直接的な破壊効果を定量的に 評価するために, 曝気前の水温 $T_{0}$ と曝気後の水温 $T$ との 差分 $\left(T-T_{0}\right)$ を求めた。一例として, 曝気流量が $1.4 \mathrm{Nm}^{3} / \mathrm{min}$ の場合（14min 後）をFig. 8 の（a）図, $0.7 \mathrm{Nm}^{3} / \mathrm{min}$ の場 合（13min 後）を同（b）図に示す. 水温の低下部分を青, 上昇部分を赤で示す。また, 半径 $r$ が $0,5,10,15 \mathrm{~m}$ での各值 を抽出したものをFig. 9 に示している.これらより, 装置 真上から半径 $r=10 \mathrm{~m}$ または $8 \mathrm{~m}$ までの浅層で特に, 水温 の低下量が大きいことがわかる。
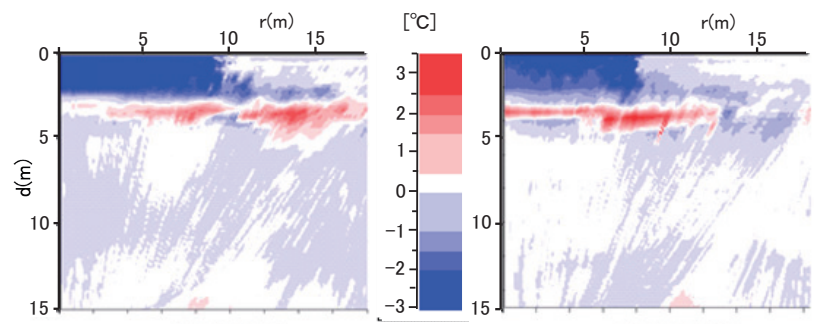

(a) $Q_{a}=1.4 \mathrm{Nm}^{3} / \mathrm{min}, t=14 \mathrm{~min}$ (b) $Q_{a}=0.7 \mathrm{Nm}^{3} / \mathrm{min}, t=13 \mathrm{~min}$

Fig. 8 Water temperature change from initial condition
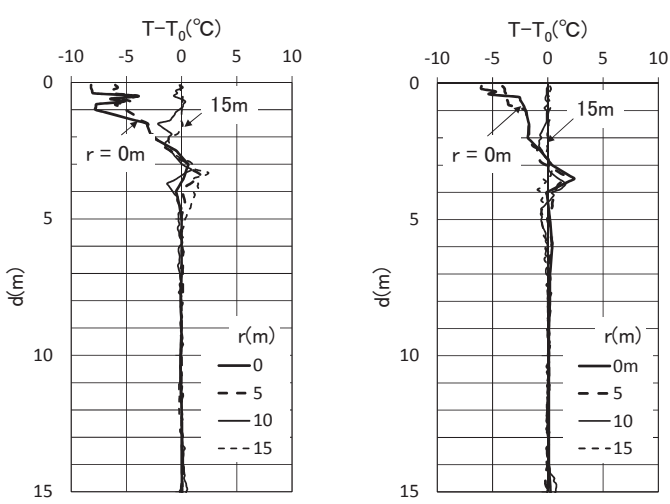

(a) $Q_{a}=1.4 \mathrm{Nm}^{3} / \mathrm{min}, t=14 \mathrm{~min} \quad$ (b) $Q_{a}=0.7 \mathrm{Nm}^{3} / \mathrm{min}, t=13 \mathrm{~min}$

Fig. 9 Water temperature change from initial condition

Fig. 8 と 9 に示したような水温分布が装置上方に同心円 状に広がっていると仮定し，その水温差と躍層破壊範囲の 体積 $V$ から, 躍層の熱的破壊効果を定量的に示寸指数 $I_{d}$ （Direct destruction Index of thermocline）を次式：

$$
I_{d}=\int\left|T-T_{0}\right| d V
$$

で定義して導入した。単位は ${ }^{\circ} \cdot \mathrm{m}^{3}\left(\right.$ または $\mathrm{K} \cdot \mathrm{m}^{3}$ ) であ り, これに水の密度 $\rho_{w}\left(\mathrm{~kg} / \mathrm{m}^{3}\right)$ と比熱 $C(\mathrm{~J} / \mathrm{kg} \cdot \mathrm{K})$ をか けると, この範囲における熱量の変化分 $\Delta Q$ :

$$
\Delta Q=\rho C \cdot I_{d}
$$

が得られることになる. 各空気流量 $\left(1.4\right.$ と $0.7 \mathrm{Nm}^{3} / \mathrm{min}$ ) に対する躍層破壊範囲として, 半径 $r$ を $10 \mathrm{~m}$ と $8 \mathrm{~m}$ とした. 水深 $d$ に関しては, 水温変化の中立線となる $d_{c}=2.7 \mathrm{~m}$ を 基準にして，その上方を冷却域，下方 $5 \mathrm{~m}$ までを加熱域と し，それぞれの成分 $\left(I_{c}, I_{h}\right)$ に分けて算出した。 したが って, $I_{c}$ と $I_{h}$ の合算值が破壊指数 $I_{d}$ :

$$
I_{d}=I_{c}+I_{h}
$$

となる. 求めた破壊指数 $I_{d}$ とその内訳 $\left(I_{c}, I_{h}\right)$ および熱 量変化分 $Q$ を Table. 1 に示す. 空気流量 $Q_{a}$ が半分になる 
と, 破壊指数 $I_{d}$ の值も概ね半分になっている.

曝気前後の水温変化より, 増加した成層のポテンシャル エネルギー $\Delta E_{p}$ が, 次式より求められる.

$$
\Delta E_{p}=2 \pi g \int r z \cdot\left\{\rho_{w}(T)-\rho_{w}\left(T_{0}\right)\right\} d z d r
$$

ただし, $\rho_{w}\left(T_{0}\right)$ と $\rho_{w}(T)$ とは, 曝気前後の水温 $\left(T_{0}\right.$ と $\left.T\right)$ に おける水の密度, $z$ は上方を正とする位置座標, $g$ は重力 加速度を示す. 先に示した躍層破壊範囲に限定して, $\Delta E_{p}$ を求めたものを Table 2 に示す. 空気流量 $Q_{a}$ が半分にな ると，これらの位置エネルギーも概ね半分になっている. 参考までに, 散気水深 $d_{a}$ が $10.6 \mathrm{~m}$ への空気塊投入動力 $P_{a}$

$$
P_{a}=p_{0} Q_{a} \ln \left(\rho_{w} g d / p_{0}+1\right)
$$

と，それを基準にした混合効率 $\eta$ :

$$
\eta=\Delta E_{p} /\left(P_{a} t\right)
$$

を計算したものを併せて Table 2 に示す. 効率値は Asaeda $ら^{3)}$ の模型実験の值（約 5\%）より小さい。これは，ここ で示した範囲外へのエネルギーの散逸があるからである。

Table. 1 直接的な躍層破壊域の熱量変化

\begin{tabular}{|c|c|c|c|}
\hline $\begin{array}{c}Q_{a} \\
{\left[\mathrm{Nm}^{3} / \mathrm{min}\right]}\end{array}$ & $r \times d_{c}[\mathrm{~m}]$ & $\begin{array}{c}I_{d}\left(I_{c}, I_{h}\right) \\
{\left[\times 10^{3}{ }^{\circ} \mathrm{C} \cdot \mathrm{m}^{3}\right]}\end{array}$ & $\Delta Q[\mathrm{MJ}]$ \\
\hline \multirow{3}{*}{1.4} & \multirow{3}{*}{$10 \times 2.7 \mathrm{~m}$} & $I_{d}: 2.82$ & 11.6 \\
\cline { 3 - 4 } & & $I_{c}: 2.52$ & $(-) 10.4$ \\
\cline { 3 - 4 } & & $I_{h}: 0.30$ & $(+) 1.22$ \\
\hline \multirow{3}{*}{0.7} & \multirow{3}{*}{$8 \times 2.7 \mathrm{~m}$} & $I_{d}: 1.56$ & 6.45 \\
\cline { 3 - 4 } & & $I_{c}: 1.28$ & $(-) 5.28$ \\
\cline { 3 - 4 } & & $I_{h}: 0.28$ & $(+) 1.17$ \\
\hline
\end{tabular}

Table. 2 直接的な躍層破壊域の位置エネルギー増加

\begin{tabular}{|c|c|c|c|}
\hline$Q_{a}\left[\mathrm{Nm}^{3} / \mathrm{min}\right]$ & $P_{a}[\mathrm{~W}]$ & $\Delta E_{p}[\mathrm{~kJ}]$ & $\eta[\%]$ \\
\hline \multirow{2}{*}{1.4} & 1669 & 26.4 & \multirow{2}{*}{1.9} \\
\cline { 2 - 2 } & $\left(d_{a}=10.6 \mathrm{~m}\right)$ & $(14 \mathrm{~min}$ 後 $)$ & \\
\hline \multirow{2}{*}{0.7} & 835 & 13.2 & \multirow{2}{*}{2.2} \\
\cline { 2 - 2 } & $\left(d_{a}=10.6 \mathrm{~m}\right)$ & $(13 \mathrm{~min}$ 後 $)$ & \multicolumn{2}{|c|}{2.2} \\
\hline
\end{tabular}

Fig. 8 に示した結果からは, 躍層破壊におけるもう一つ 重要な事柄が確認できる. 直接的な躍層破壊範囲より外側 （半径 $r>10$ または $8 \mathrm{~m}$ ) で, 半径方向に水平に伸びる水 温の変化を示す細長い領域がある. 躍層の直接破壊範囲を 決定する際に採用した, 水温変化の中立水深 $\left(d_{c}=2.7 \mathrm{~m}\right)$ の上層では水温は低下し, 下層では上昇している。この部 分は, 中層より連行された水塊が真上の躍層を直接破壊し た後, 等密度の水深へと水平に貫入するイントリュージョ ンを示していると推測される.今回の実験では, 装置近傍 の直接的な躍層破壊の過程に着目して, 短時間かつ狭範囲 の計測を行ったが, このイントリュージョンが長時間をか けて, 徐々に貯水池全体の躍層を破壊することになる.

Table 2 に示した効率值が Asaeda ら ${ }^{3)}$ のそれより小さか ったのは, このイントリュージョンの水温変化を除いたた めである.なお、貯水池全体の躍層破壊については, 翌
2012 年に広範な実験を行っているので, 追って報告する.

\section{5. 流速計測による流れの可視化}

\section{1. 計測の方法}

装置上方周辺の流速分布を計測するため, 二次元電磁流 速計（JFE アレック，AEM213-D）を使用した。流速計の センサー部分は直径 $5 \mathrm{~cm}$, 長さ $30 \mathrm{~cm}$ の円柱形で, 円柱の 長手方向に直行する二次元断面での流速が計測できる. セ ンサー部分を計測用フロートの中央に加工された穴から， 計測用ケーブルを携えたロープを介して水中に沈めた。ロ ープはフロートの上部で，ロープ固定用フレームと滑車に よって，任意の深さに調整・固定が簡単にできるよう工夫 し, 他端には錘 (真鍮, 質量 $3.5 \mathrm{~kg}$ ) を付けて鉛直を保持 した。計測深さは, 水面から水深 $1 \mathrm{~m}$ までは密に, それよ り深いところでは粗く設定した。計測は本実験 3 日目（8 月 18 日), 気泡噴流が水面に表れてから 30 分以上経過し た比較的安定な状態で実施し, 各計測点で原則 30 秒の時 間をかけて平均流速を求めた。このような計測を, 曝気装 置真上より南側に $3.5,6.0 ， 10 ， 15 \mathrm{~m}$ および北側に $3.5 \mathrm{~m}$ 離れた位置で実施した，位置設定の誤差は，風によって水 面上のフロートが少し流される場合があるため, 東西に概 ね $\pm 0.5 \mathrm{~m}$ である. 実験時の貯水池環境から, 装置を運転し なければ水の流れはほとんどなく, また後述する水面の状 態からも, 装置による擾乱は概ね同心円状に広がると推測 できた。このため，水温と流速との計測位置が南北に異な っても, 同じ方向で得たものと大差ないと判断した.

\section{2. 計測結果}

空気流量が $1.4 \mathrm{Nm}^{3} / \mathrm{min}$ の場合に得られた流速の計測結 果をFig. 10 に示す. 装置に近い $3.5 \mathrm{~m}$ 地点では, 南・北側 ともに水面近くで $30 \mathrm{~cm} / \mathrm{s}$ 程度になるが, 水深とともに急 激に小さくなり, $1 \mathrm{~m}$ より深いところでは $10 \mathrm{~cm} / \mathrm{s}$ を下回る. 流向はややばらつきがあるが, 南・北側のデータを併せて 考えると, 水面付近では装置から離れる方向（半径方向） に, それより少し深くなると装置を中心に反時計回りに緩 やかに回転しながら中心に向からと推測できる．南側 $6 \mathrm{~m}$ の地点では, 水面付近での流速が $3.5 \mathrm{~m}$ の地点に比べてや や小さい. 流向は, 水面近くでは装置から離れる方向であ るが, 水深が深くなるにつれて装置に近づく方向へと滑ら かに変化する. 南側 $10 \mathrm{~m}$ の地点では, 水面近くの流速が さらに小さい. 流向は興味深い分布を示す. 水面近くでは, 装置から離れる流れと近づく逆の流れが観測され, 水深が 深くなると概ね装置から離れる流れとなる。南側 $15 \mathrm{~m} の$ 地点では，流速は全体的に小さくなる．流向についてはデ ータのばらつきが大きいが, 水面近くでは装置に近づく方 向, 水深が深くなると装置から離れる方向と判断できる.

以上の流れの分布を全て併せて考慮すると, Fig. 11 に 示すような流れのプロファイルが解析できる. 装置から放 出される気泡群は, 周辺の水塊を緩やかに左回りに巻き込 
みながら表層まで連行し, 連行された水はその後, 水面近 くで装置から離れるように周辺に拡がる.さらに半径 $10 \mathrm{~m}$ 付近で, 水深 $3 \mathrm{~m}$ 付近まで潜り込んで水平に拡がる.これ に対応するような二次循環流が, 半径 $10 \mathrm{~m}$ 以上の範囲で 発生している. 水面付近での連行流の前線位置は一定では なく, 半径 $10 \mathrm{~m}$ の位置を中心にして前進・後退を繰り返 しながら時間的に変動している。

曝気流量が $0.7 \mathrm{Nm}^{3} / \mathrm{min}$ の場合は, 紙面の都合により詳 細なデータは割愛するが, 得られた流速值から解析すると, Fig. 10 と同様ではあるが半径方向にやや規模の小さい循 環構造がみられ, 連行流の前線位置は約 $8 \mathrm{~m}$ と推測された.

なお，これらの流れのプロファイルは，いずれの空気流 量の場合も, 寸でに得られた水温分布特性とよく対応する.

Horizontal velocity amplitude $u(\mathrm{~cm} / \mathrm{s})$
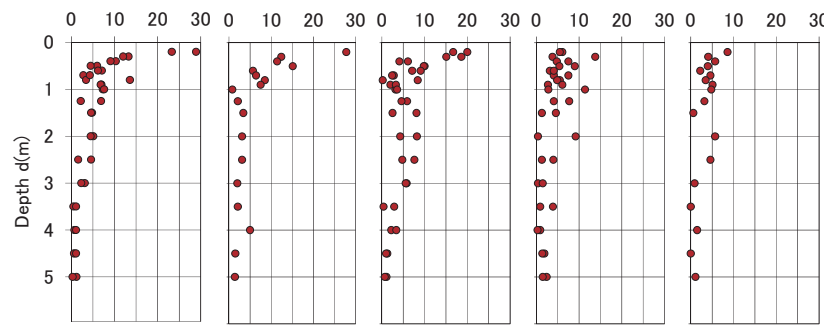

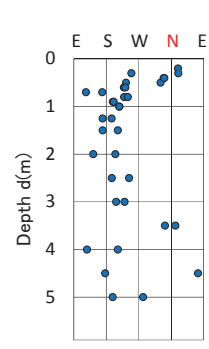

(a) $\mathrm{N} 3.5 \mathrm{~m}$

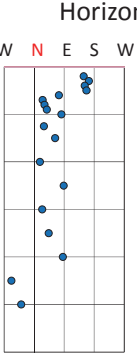

(b) $\mathrm{S} 3.5 \mathrm{~m}$

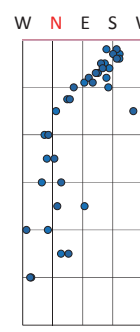

(c) S $6 \mathrm{~m}$

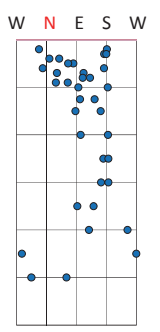

(d) S_10m

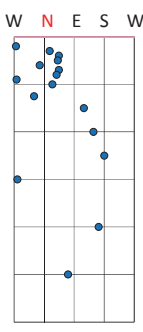

(e) S_15m
Fig. 10 Horizontal velocity distribution for $Q_{a}=1.4 \mathrm{Nm}^{3} / \mathrm{min}$.

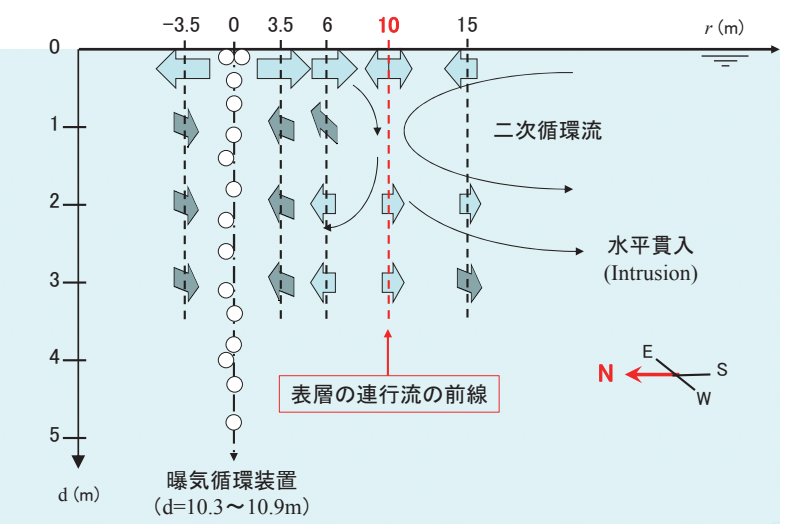

Fig. 11 Estimated flow profile for $Q_{a}=1.4 \mathrm{Nm}^{3} / \mathrm{min}$.

\section{6. 貯水池表層への濁水連行とイントリュージョン}

\section{1 . 濁水の撮影画像}

貯水池中層（水深約 $10 \mathrm{~m}$ ) の水は当該装置の気塊放出に よって表層に連行される. 今回の実験では幸いにもそれ以
深に濃い濁水が滞留していたため, それをトレーサーとし て連行流の広がりを調べることができた.

Fig. 12 に, 水面に濁水が広がる様子を撮影した写真を 示寸. 撮影日は 8 月 9 日（予備実験日）で，このときの供 給空気流量は $1.4 \mathrm{Nm}^{3} / \mathrm{min}$ であった. いずれも北岸のコン プレッサー室近傍より撮影したものである. 曝気開始時刻

（気泡が最初に水面に到達した時刻）は11:05 であり，そ れから 27 分後までの代表的な写真を選んでいる. 図(a) はその 5 分後の写真である. 形状が若干いびつではあるが, すでに直径約 $20 \mathrm{~m}$ の円状に濃い濁水が広がっている. 興 味深いことは，その濃い濁水の外側に，点線で示した薄い 濁水の広がりが確認できることである.さらに時間が経過 すると図 (b) と (c) に示すように, 濃い濁水の領域は変化し ない一方, 薄い濁水の領域は拡大を続けている. 27 分後 の図 (d) からは, 濁水が網場の近くまで到達している様子 がわかる. 水温と流速の結果を併せて考慮すると, 濃い濁 水が表層の躍層破壊範囲に対応し, 薄い濁水が水深 $2.7 \mathrm{~m}$ で見られたイントリュージョンに対応すると推測できる.

上記の曝気開始の 41 分後（11:46）より，速やかに空気 流量を $0.7 \mathrm{Nm}^{3} / \mathrm{min}$ に変更した. それから約 30 分後に水面 を撮影した写真を，先に示した曝気流量 $Q_{a}$ が $1.4 \mathrm{Nm}^{3} / \mathrm{min}$ の場合と併せて Fig. 13 に示寸. 濃い濁水の範囲は直径約 $16 \mathrm{~m}$ となり, 曝気流量が $1.4 \mathrm{Nm}^{3} / \mathrm{min}$ の場合より明らかに 小さい. しかし, 薄い濁水の範囲はさらに広がっている.

ビデオカメラで撮影した映像から，この濁水の拡散範囲 の時系列変化 (40 分間) を, 南北および東側で解析した. それをFig. 14 に示寸. 濁水の半径は最初急激に拡大し, その後ほぼ一定の速度で広がっている，その速度は 1 〜 $1.5 \mathrm{~m} / \mathrm{min}(2 \sim 3 \mathrm{~cm} / \mathrm{s})$ である. 寸でに Fig. 10 に得られて いる直接的な計測值からこれに対応する值を選ぶと，図

(e) の半径 $r=15 \mathrm{~m}$ の水深 $2 \sim 3 \mathrm{~m}$ 付近の值（約 $5 \mathrm{~cm} / \mathrm{s}$ ）が 適切であろう。こちらの方がやや大きいが，その理由はイ ントリュージョン先端の濁度が低く, 水面上で十分な色の 変化が確認できなかったものと考えられる.

\section{7. イントリュージョン流量の推定}

これまでに得られた結果から, 装置真上の冷水塊より水 深 $3 \mathrm{~m}$ 付近へ貫入するイントリュージョンの存在が明らで ある。ここでは, 流速の計測結果より, その流速 $v_{i}$ を特定 し, 周辺への貫入面積 $2 \pi r \Delta d_{i}$ を掛け，流量 $Q_{i}$ :

$$
Q_{i}=2 \pi r \Delta d_{i} v_{i}
$$

を算定した。流速 $v_{i}$ と貫入厚さ $\Delta d_{i}$ は, Fig. 10 (e) の水 深 $3 \mathrm{~m}$ 付近のデータ $\left(Q_{a}=1.4 \mathrm{Nm}^{3} / \mathrm{min}\right)$ からそれぞれ, $5.0 \mathrm{~cm} / \mathrm{s}$ と $1.0 \mathrm{~m}$ と粗く見積もった。 その結果，イントリュージョ ン流量 $Q_{i}$ は約 $280 \mathrm{~m}^{3} / \mathrm{min}\left(4.7 \mathrm{~m}^{3} / \mathrm{s}\right)$ となり, 空気流量 $Q_{a}$ に対する連行倍率は 200 倍となる。この流量を基準に, 当 該貯水池の浅層循環に要する日数を求めた。 その結果, 本 装置 1 基で，貯水池浅層 $5 \mathrm{~m} （ 175.1 \sim 180.1$ E.L.m.） に相当 
する貯水量 $\left(6,926 \times 10^{3} \mathrm{~m}^{3}\right)$ を対象とすれば約 17 日, Fig. 1 に示した堤体近くの比較的閉鎖された水域 (全貯水面積の 約 1/7）に限定すれば約 2.4 日で計算上, 対象水塊の一循 環を完了することになる.

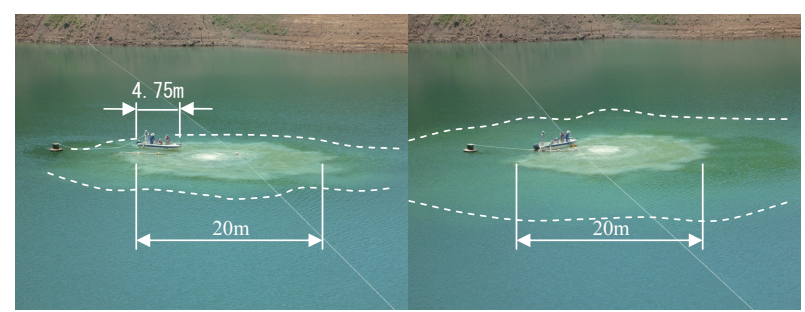
(a) $t=5 \mathrm{~min}$

(b) $t=12 \mathrm{~min}$

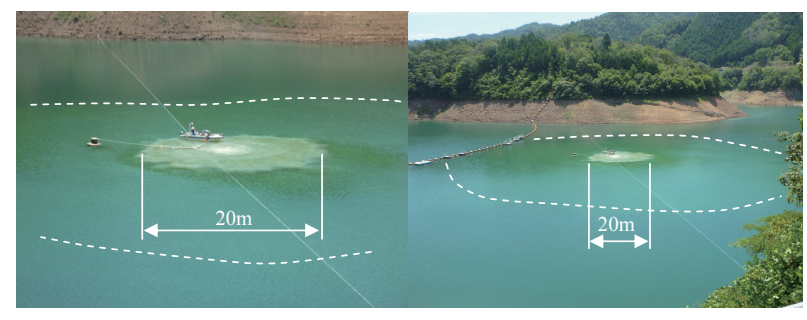

(c) $t=24 \mathrm{~min}$

(d) $t=27 \mathrm{~min}$

Fig. 12 Pictures of spreading muddy water for $Q_{a}=1.4 \mathrm{Nm}^{3} / \mathrm{min}$ (8/9 11:05 ).

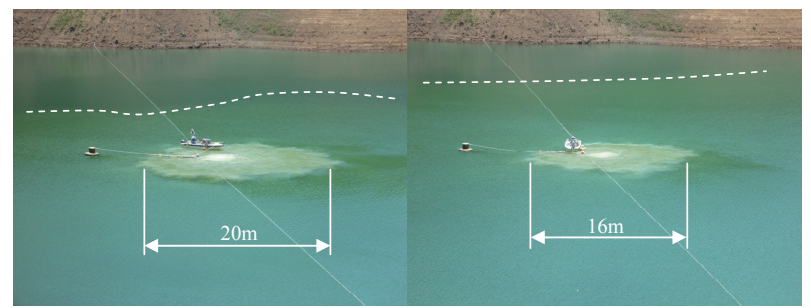

(a) $Q_{a}=1.4 \mathrm{Nm}^{3} / \mathrm{min}(t=27 \mathrm{~min})$ (b) $Q_{a}=0.7 \mathrm{Nm}^{3} / \min (t=31 \mathrm{~min})$

Fig. 13 Comparison of range of light muddy water for different air flow rate $Q_{a}$.

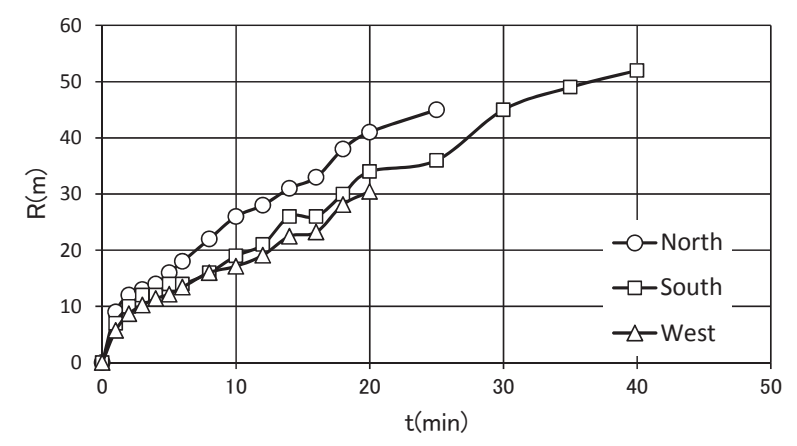

Fig. 14 Time history of increasing radius of dark muddy water for $Q_{a}=1.4 \mathrm{Nm}^{3} / \mathrm{min}$.

\section{8. まとめ}

日吉ダム貯水池に導入された曝気循環装置の性能評価の 一環として, 浅層循環効果を調査する実験を, 現地にて 2011 年 8 月に実施した。結果は以下の通り要約できる.

（1）装置周辺の水温計測結果から, 浅層の水温躍層は, 空気流量が $1.4 \mathrm{Nm}^{3} / \mathrm{min}$ の場合に半径 $10 \mathrm{~m}$, 曝気流量が $0.7 \mathrm{Nm}^{3} / \mathrm{min}$ の場合に半径 $8 \mathrm{~m}$ の範囲で, いずれも水深約 $3 \mathrm{~m}$
まで直接的に破壊されること，それが曝気開始後約 10 分 で完了すること, さらにその破壊域は 1 2 分の周期で拡 大・収縮を繰り返すことを明らかにした，また，その外縁 より周辺に伸びるイントリュージョンを確認した。

（2）気泡噴流による躍層の直接的な破壊効果を，熱量お よび位置エネルギーの変化から定量的に求めることがで き，それらが空気流量とよく対応することを明らかにした。

(3) 流速の計測結果から, 温度計測結果に対応した連行 流の循環構造と周囲の 2 次循環流を確認した.

(4) 曝気装置上方水面より撮影された濁水の拡散画像か ら，水温および流速の計測結果を裏付ける結果を得た。

（５）イントリュージョンの流量は，空気流量が $1.4 \mathrm{Nm}^{3} / \mathrm{min}$ の場合で約 $280 \mathrm{~m}^{3} / \mathrm{min}\left(4.7 \mathrm{~m}^{3} / \mathrm{s}\right)$ となり, 空気 流量に対して 200 倍となった.

\section{謝 辞}

実地調査実験の実施にあたり, 大阪電気通信大学工学部 環境技術学科の北川健太君, 澤村健司君, 谷村幸彦君, 寺 阪太佑君, 夏井清成君, 野本真広君, 早藤大輔君に多大な ご協力を頂いた．ここに厚く御礼申し上げる.

\section{参考 文 献}

1）有田正光, 他：水圈の環境, 東京電機大学出版局, (2005), pp. 263-264.

2) Mcdougall, T. J. : Bubble plumes in stratified environments, Journal of Fluid Mechanics, Vol.4(1978) pp. 655-672.

3) Asaeda, T., Imberger, J. : Structure of bubble plumes in linearly stratified environments, Journal of Fluid Mechanics, Vol.249(1993) pp. 35-57.

4）松梨史郎, 宮永洋一: 気泡噴流に関する現地実験, 水工学論 文集, Vol. 34 (1990), pp. 145-150.

5）丹羽薰, 久納誠, 大西実, 山下芳浩 : 貯水池流動制御による 水質保全対策，水工学論文集，37 (1993) pp. 271-276.

6）豊島靖, 天野邦彦, 田中康泰 : ダム貯水池における曝気循環 による成層破壊状況の現地観測と評価, 水工学論文集, Vo1. 47 (2003) pp. 1243-1248.

7）梅田信, 宮崎貴紅子, 富岡誠司 : 曝気式循環施設により生じ る貯水池内流動の現地観測, 土木学会論文集, Vol. 775 (2004) pp. 55-68.

8）岩松裕二, 中田亮生, 小阪公則, 佐藤友宣, 山岸真孝: ダム 貯水池における水没式複合型曝気循環装置の浅層循環に関 する実地調查実験 (水温躍層の直接破壊領域の可視化と散気 部形状による水連行効果の検討), 水環境学会論文集, Vo1.37, No. 2 (2014) pp. 63-69.

9) Imberger, J., Ivey, G. N. : On the Nature of Turbulence in a Stratified Fluid. Part II: Application to Lakes, Journal of Physical 0ceanography, Vo1.21, No. 5 (1991), pp. 659-680.

10) McGinnis, D. F., Lorke, A., Wüest, A., Stöckli, A., Little, J. C. : Interaction between a bubble plume and the near field in a stratified lake, Water Resources Research, Vol. 40, No. 10 (2004) W10206.

11) Singleton, V. L., Gantzer, P., Little, J . C. : Linear bubble plume model for hypolimnetic oxygenation: 
Ful1-scale validation and sensitivity analysis, Water Resources Research, Vo1.43(2007) W02405. 